\title{
When Less is More: A Significant Risk Threshold For CERCLA Liability
}

\author{
Evan Bogart Westerfield $\dagger$ \\ "What mighty contests rise from trivial things"1
}

The Comprehensive Environmental Response, Compensation, and Liability Act ("CERCLA") 2 establishes an array of regulatory and judicial mechanisms designed to address the health risks and other problems associated with improperly disposed hazardous wastes. One of these mechanisms, the cost recovery action, authorizes federal and state governments as well as private citizens to remedy sites contaminated with hazardous wastes and then bring suit to recover the costs of this cleanup from "responsible" parties." CERCLA's drafters believed that such suits would help defuse the nation's toxic time bomb ${ }^{4}$ rapidly and at the polluters' expense. ${ }^{5}$

The centerpiece of the cost recovery mechanism is an expansive liability scheme. CERCLA makes liable an enormously broad range of parties, including many that would surely escape liability

† B.A., 1986, Yale University; M.A., 1989, The University of Chicago; J.D., 1993, The University of Chicago.

'Alexander Pope, The Rape of the Lock, Canto I, In 1 (Oxford, 1966) (originally published in 1736).

2 Pub L No 96-510, 94 Stat 2767 (1980), codified at 42 USC \$§ 9601-9675 (1988).

342 USC § 9607(a); Pennsylvania v Union Gas Co., 491 US 1, 21-22 (1989); Walls $v$ Waste Resource Corp., 761 F2d 311, 318 (6th Cir 1985); Artesian Water Co. $v$ New Castle County, 659 F Supp 1269, 1277 (D Del 1987), aff'd, 851 F2d 643 (3d Cir 1988).

- For a discussion of the extent of this hazardous waste problem, see generally Environmental Emergency Response Act, S Rep No 96-848, 96th Cong, 2d Sess 2-12 (1980); Hazardous Waste Containment Act of 1980, HR Rep No 96-1016, Pt 1, 96th Cong, 2d Sess 17-21 (1980), reprinted in 1980 USCCAN 6119; Samuel S. Epstein, Lester O. Brown, and Carl Pope, Hazardous Waste in America (Sierra Club, 1982). It is estimated that over 300 million metric tons of hazardous waste are now disposed of each year in the United States, Philip Shabecoff, Major Federal Program is Urged to Cut Flow of Hazardous Waste, NY Times A23 (Jun 26, 1987), and that between 130,000 and 380,000 sites eventually may have to be reviewed as potential candidates for government initiated response actions under CERCLA. EPA Superfund Study Advises Congress of Potential for 'Dramatic' Program Increase, 15 Envir Rep 1395 (BNA) (1984).

- See S Rep No 96-848 at 12-13 (cited in note 4); United States v Reilly Tar \& Chemical Corp., 546 F Supp 1100, 1112 (D Minn 1982). 
under traditional common law principles. ${ }^{6}$ Parties may have to bear the full cost of cleanup, for instance, even if they disposed of their wastes according to prevailing law ${ }^{7}$ and even if no evidence shows that their wastes, rather than someone else's, caused the contamination at the site. ${ }^{8}$ Such sweeping liability may seem unfair, but CERCLA's drafters insisted that the drastic nature of the hazardous waste problem necessitated just such a drastic solution. ${ }^{9}$

Recently, some courts have extended CERCLA's already wide liability net even further, holding that parties can be liable even if the hazardous materials they discharged into the environment posed only very low risks of harm. ${ }^{10}$ According to these courts, CERCLA liability attaches to all releases of toxic wastes; exempting some releases because they threaten little or no danger-in other words, fashioning a "significant risk threshold" for liability-would contradict CERCLA's plain language and undermine its beneficial purposes.

This Comment will argue that this rejection of a significant risk threshold for CERCLA liability, while perhaps appealing at first, is quite misguided. Refusing to exempt releases posing only de minimis risks is problematic not only because it leads to absurd results and unjust outcomes, as some have observed, ${ }^{11}$ but also because it misunderstands CERCLA itself. As this Comment will show, a significant risk threshold does have a solid basis in the

- John J. Lyons, Deep Pockets and CERCLA: Should Superfund Liability Be Abolished? 6 Stan Envir L J 271, 286-99 (1987) (tracing the areas in which CERCLA liability diverges from traditional tort law).

7 See, for example, United States v Mottolo, 695 F Supp 615, 622 (D NH 1988) (CERCLA liability encompasses cleanup costs resulting from acts that occurred prior to CERCLA's enactment); United States v Dickerson, 640 F Supp 448, 451 (D Md 1986) (compliance with existing laws and exercising reasonable care at the time of disposal does not constitute a defense to CERCLA liability).

${ }^{8}$ Dedham Water Co. v Cumberland Fárms Dairy, Inc., 889 F2d 1146, 1154 (1st Cir 1989) (unnecessary for plaintiff to prove that its property was contaminated by hazardous substances actually belonging to defendant).

- 126 Cong Rec 30931-32 (Nov 24, 1980) (remarks of Senator Randolph, Chairman of the Senate Committee on Environment and Public Works) ("[g]ranted, the scope of such legislation was considerable, but the problem is considerable").

${ }^{10}$ Mid Valley Bank v North Valley Bank, 764 F Supp 1377, 1386-87 (E D Cal 1991); United States v Alcan Aluminum Corp., 755 F Supp 531, 537-39 (N D NY 1991) ("Alcan I"); City of New York v Exxon Corp., 766 F Supp 177, 195-96 (S D NY 1991); United States $v$ Western Processing Co., Inc., 734 F Supp 930, 941-42 (W D Wash 1990).

${ }_{11}$ Developments in the Law-Toxic Waste Litigation, 99 Harv L Rev 1458, 1554 (1986) ("Courts should allow defendants to raise a defense when the costs of a cleanup are obviously disproportionate to the benefits."); United States $v$ Stringfellow, 20 ERC (BNA) 1905,1910 (C D Cal 1984) (implicitly noting the inequity of holding a small contributor of hazardous substances to a site liable for all site response costs). 
statutory language and is entirely consistent with CERLCA's purposes. In fact, it is the rejection of such a threshold test, and not the threshold itself, that truly frustrates CERCLA's beneficial purposes.

This Comment develops this argument in six sections. Section I sketches the basic mechanics of CERCLA's liability scheme. Section II reviews the case law that rejects a significant risk threshold for CERCLA liability. Section III shows that a threshold has a firm basis in the statutory language. Section IV finds support for a threshold in CERCLA's legislative history. Section V shows that such a threshold is not only compatible with CERCLA's purposes, but even advances them. Finally, Section VI responds to concerns that the implementation of such a threshold would be impractical due to the limitations of quantitative risk assessment and the likelihood of abuse in multi-polluter contexts.

\section{CERCLA's Liability Scheme}

The liability scheme governing cost recovery actions under CERCLA is relatively straightforward. In order to recover their costs of cleanup, plaintiffs must make a five-part showing: (1) that the defendant is a "covered person," and (2) that a "release" or "threatened release" of (3) a "hazardous substance" at (4) a "facility" has (5) "cause[d] the incurrence of response costs."12 This burden is not heavy. The first element, "covered person," includes anyone who falls into one of four categories of "potentially responsible persons" ("PRPs"): (1) current owners or operators of the contaminated site, (2) former owners and operators who owned or operated the site at the time of the disposal of hazardous materials, (3) generators of hazardous materials that came to be located at the site, and (4) persons who transported hazardous materials to the site. ${ }^{13}$ These categories, moreover, have consistently received broad judicial construction, ${ }^{14}$ such that, as the United States Su-

1242 USC \$ 9607(a). Courts disagree over whether plaintiffs must also show, as part of their prima facie case, that their cleanup costs are consistent with the National Contingency Plan (NCP), a document promulgated by the EPA specifying the manner in which cleanup operations should be conducted. Compare Western Processing, 734 F Supp at 942 ("[t]he language concerning costs consistent with the [NCP] should not be considered an element for demonstrating liability"), with Artesian Water, 659 F Supp at 1291 (plaintiff's response actions must be consistent with the NCP).

1342 USC $\S 9607(\mathrm{a})(1)-(4) ; 42$ USC $\S 9601(20)(\mathrm{A})-(\mathrm{C})$.

14 See, for example, In re T.P. Long Chemical, Inc., 45 Bankr 278, 283-4 (Bankr N D Ohio 1985) (bankruptcy estate may become owner of a facility); United States $v$ Maryland Bank \& Trust Co., 632 F Supp 573, 578-80 (D Md 1986) (foreclosing bank may constitute 
preme Court observed, "everyone who is potentially responsible for hazardous waste contamination may be forced to contribute to the costs of cleanup."15 The second element, "release," covers any spilling, dumping, pouring, emitting, leaching, leaking, escaping-in other words, virtually any way a hazardous substance could enter the general environment. ${ }^{16}$ The third element, "hazardous substance," covers any substance simply designated as "hazardous" by any of several environmental statutes,;7 proof that the amount of substances at the site is sufficient to be actually hazardous or dangerous is not necessary for this particular aspect of the prima facie case. ${ }^{18}$ Finally, the fourth element, "facility," refers tautologically to any place where hazardous substances have "come to be located."19 Establishing these elements, then, does not require elaborate proof.

However, the last requirement-that the release "cause the incurrence of response costs"-does demand a more precise showing. First, not all expenses related to a release of hazardous substances constitute "response costs." Response costs do not include, for instance, the costs of personal injuries or "economic harms that result from discharges of hazardous substances."20 Instead, plaintiffs must show that their costs result from long-term cleanup procedures designed to restore environmental quality or from short-term

owner of a facility); Quadion Corp. $v$ Mache, 738 F Supp 270, 274 (N D Ill 1990) (shareholders of a closely held corporation may be liable "even in absence of facts which would warrant piercing the corporate veil"); Smith Land \& Improvement Corp. v Celotex Corp., 851 F2d 86, 92 (3d Cir 1988) (successor corporation liable under CERCLA).

${ }_{10}$ Pennsylvania v Union Gas Co., 491 US 1, 21 (1989) (states and municipalities may be liable under CERCLA) (emphasis in original).

1642 USC § 9601(22); United States v Metate Asbestos Corp., 584 F Supp 1143, 1149 (D Ariz 1984) ("release" occurs when substances are blown by the wind); Vermont $v$ Staco, Inc., $684 \mathrm{~F}$ Supp 822, 833 (D Vt 1988), rescinded in part, vacated in part on other grounds, 31 ERC (BNA) 1814 (1989) ("release" occurs when substances are carried out of a manufacturing facility on the clothes of a worker). Moreover, an actual release is not always necessary; a "threatened release" may also lead to liability. According to the courts, this term covers any situation that "may reasonably be anticipated to pose a threat to the environment." Velsicol Chemical Corp. v Reilly Tar \& Chemical Corp., 15 Envir L Rep 20103, 20104 (E D Tenn 1984). See also New York v Shore Realty Corp., 759 F2d 1032, 1045 (2d Cir 1985) ("Corroding and deteriorating tanks, [ ] lack of expertise in handling hazardous waste, and even the failure to license the facility, amount to a threat of release.").

${ }^{17} 42$ USC § 9601(14).

18 United States v Alcan Aluminum Corp., 964 F2d 252, 260-61 (3d Cir 1992) ("Alcan II"); Amoco Oil Co. $v$ Borden, Inc., 889 F2d 664, 669 (5th Cir 1989).

${ }_{19} 42$ USC § 9601(9)(B).

${ }^{20}$ Exxon Corp. $v$ Hunt, 475 US 355, 359 (1986). "Superfund money may not be used to pay for injury to persons ...." Id at 360. See also, Comment, When Does Going to the Doctor Serve Public Health? Medical Monitoring Response Costs Under CERCLA, 59 U Chi L Rev 925, 925 (1992). 
measures necessary to monitor and abate the immediate effects of a contamination problem. ${ }^{21}$ Second, the release must actually "cause" the incurrence of response costs. In other words, plaintiffs must show some "causal connection between [the] release or threatened release and the incurrence of costs" in order to prove liability. ${ }^{22}$

Once plaintiffs make this five-part showing, however, they "need prove nothing more." ${ }^{23}$ CERCLA imposes strict, ${ }^{24}$ retroactive, ${ }^{25}$ and, usually, joint and several liability, ${ }^{28}$ and thus plaintiffs need not demonstrate that the defendants represent the primary contributors to the site or that they acted negligently. In addition, CERCLA relaxes the traditional causation requirement; while plaintiffs must show a link between the release and their damages, they do not have to show a link between the release and the particular defendant. Liability will exist, in other words, even without hard evidence that the contamination was caused by this, rather than another, party. ${ }^{27}$ Indeed, once the plaintiffs have established the prima facie case, the defendants will avoid liability only if they can affirmatively exonerate themselves by means of three narrowly circumscribed defenses. ${ }^{28}$

21 42 USC \$\$ 9601(23) \& (24). CERCLA does not in fact define response costs, but it does define response actions as "removal [ ] and remedial action." 42 USC § 9601(25). Accordingly, courts have resorted to the terms CERCLA does define and concluded that "response costs" are those costs incurred in performing a specified removal or remedial action. Amoco, 889 F2d at 669; $T \&$ E Industries, Inc. v Safety Light Corp., 680 F Supp 696, 705-06 (D NJ 1988).

${ }^{22}$ Artesian Water, 659 F Supp at 1282.

${ }^{23}$ United States v South Carolina Recycling and Disposal, Inc., 653 F Supp 984, 992 (D SC 1984), aff'd as United States v Monsanto Co., 858 F2d 160 (4th Cir 1988).

24 Shore Realty, 759 F2d at 1042; United States v Northeastern Pharmaceutical \& Chemical Co., 810 F2d 726, 732 n 3 (8th Cir 1986).

25 See, for example, United States v Dickerson, 640 F Supp 448, 451 (D Md 1986) (compliance with existing laws and exercising reasonable care at the time of disposal does not constitute a defense to CERCLA liability); United States $v$ Mottolo, 695 F Supp 615, 622 (D NH 1988) (CERCLA liability encompasses cleanup costs resulting from acts that occurred prior to CERCLA's enactment).

${ }^{28}$ United States v Chem-Dyne Corp., 572 F Supp 802, 808-810 (S D Ohio 1983); United States v Monsanto, 858 F2d 160, 171 (4th Cir 1988); O'Neill v Picillo, 883 F2d 176, 178-79 (1st $\mathrm{Cir}$ 1989). For a discussion of when the harm caused by toxic substances may be "divisible," see Alcan II, 964 F2d at 267-71.

${ }^{27}$ Shore Realty, 759 F2d at 1044; Monsanto, 858 F2d at 169-70.

${ }^{23} 42$ USC \& 9607(b). The defendant can try to show that the release resulted (1) from an act of war; (2) an act of God; or (3) from the acts or omissions of a totally unrelated third party. This last defense is frequently raised, but it has rarely been availing. In effect, the defendant must demonstrate that a "totally unrelated third party is the sole cause of the release." United States v Stringfellow, 661 F Supp 1053, 1061 (C D Cal 1987). 


\section{Rejection of a Significant Risk Threshold to CERCLA LIABILITY}

Since CERCLA's enactment, courts have wrestled with the question of how this liability scheme handles PRPs whose contributions to a contaminated site were, in one sense or another, "small." This issue has arisen in two different contexts: (1) when a PRP has released only a small amount of a hazardous substance and (2) when a PRP has released a hazardous substance that poses only small risks of harm. In the first situation, courts have consistently imposed liability, holding that CERCLA's liability scheme pays no heed to the quantity or concentration of the hazardous substances discharged. Defendants can be required to bear the costs of cleanup, then, even though they released less than a barrel, or even a cup, of waste. ${ }^{29}$ As these courts have observed, a volumebased exception would seriously undermine the statute's objectives because "the volume of waste . . . is not an accurate predictor of the risk associated with the waste." 30 In other words, because volume often has an indirect and coincidental relation to toxicity and hazard, the overall size of a release cannot properly affect the determination of CERCLA liability.

In the second situation, when the risks themselves are small, most courts have similarly imposed liability. As this Section will show, these courts have held that CERCLA is indifferent to whether the release in fact presents any danger; liability may be imposed regardless of the fact that the likelihood of harm is trivial.

One of the first cases to reach this conclusion was United States $v$ Alcan Aluminum Corp. ${ }^{31}$ In Alcan, the Environmental Protection Agency ("EPA") restored a contaminated site at which Alcan Aluminum, Inc., one of several defendants, had disposed of a manufacturing emulsion. ${ }^{32}$ Although the emulsion consisted primarily of water and mineral oil, it also contained trace amounts of

${ }^{29}$ South Carolina Recycling, 653 F Supp at 992; United States v Conservation Chemical Co., 619 F Supp 162, 233 (W D Mo 1985); United States v Wade, 577 F Supp 1326, 1339-41 (E D Pa 1983).

so Chem-Dyne Corp., 572 F Supp at 811.

31755 F Supp 531 (N D NY 1991). A recent appellate decision reached a similar conclusion. See United States v Alcan Aluminum Corp., 964 F2d 252 (3rd Cir 1992) ("Alcan II"). However, because the court expressly acknowledged that in some circumstances, such as single polluter contexts, risk of harm would be relevant for liability, 964 F2d at 266, Alcan $I I$ is discussed in the section dealing with multi-polluter contexts. See text accompanying notes 126-33.

${ }^{32} 755$ F Supp at 535. 
aluminum, chromium, copper, lead, zinc, and cadmium. ${ }^{33}$ The concentrations of these normally hazardous substances were so minute, however, as to be "less than background levels," that is, less than what occurs in soil naturally;" indeed, EPA never contested Alcan's repeated claims that the wastes it disposed of at this and other sites posed about as much danger as a handful of clean dirt. ${ }^{\text {s5 }}$ In addition, the waste was not water-soluble and had no migratory potential; ${ }^{36}$ in other words, just as the lead in a lead crystal glass poses no danger because it is not soluble in crystal form, Alcan's wastes were not dangerous because they too were not in a harmful form. ${ }^{37}$ Due to this absence of risk, Alcan insisted, it could not be liable under CERCLA.

The court, however, rejected this argument, holding that the actual hazard presented by a substance does not influence the question of whether CERCLA liability exists. ${ }^{38}$ It chose to focus on the third element of the prima facie case, noting that CERCLA defines "hazardous substances" to "include all substances so designated under other statutes pursuant to the grant of authority contained therein in addition to substances so designated by the EPA pursuant to [CERCLA]." According to the court, this statutory language indicates that "the mere listing of an element [or] compound," without regard to its potential for harm, "establishes that a substance is hazardous as a matter of law."40 Since elements in Alcan's waste had been designated as toxic pollutants under the Clean Water Act, the court concluded that they were hazardous under CERLCA and that liability should therefore attach. ${ }^{41}$ As the plain language of the statute made clear, risk of harm was simply not a relevant consideration. ${ }^{42}$

Other factors, the court continued, also compelled this conclusion. First, the court argued that the rejection of a significant risk

ss Id.

st Id at 536.

ss See, for example, Alcan Aluminum Corporation's Supplemental Brief in Opposition to Motion for Partial Summary Judgment, United States v Alcan Aluminum Corp., No. 3:CV-89-1657, 13 (M D Pa 1991) ("Alcan Brief") (a box of "Kellogg's Corn Flakes, vitamin tablets, and the New York Times (even the government's own amicus Brief) have much more metal compounds than the Alcan emulsion").

so Id at 7-10.

37 Id.

so Alcan $I, 755$ F Supp at 537-39.

30 Id at 537 (emphasis added).

10 Id.

41 Id at 538.

42 Id at 540 . 
threshold found support in CERCLA's legislative history. According to one Senate report:

[Those] substances listed as hazardous or toxic under certain other Federal laws are incorporated by reference .... [A]nd the release of any of them or any constituent of them invokes the ... response provisions and any costs of removal or remedial action or any damages are subject to the liability provision of the bill. ${ }^{43}$

Second, the court found that such a threshold test would be inconsistent with the statute's overriding objective: "[T]hat Congress has enacted laws to limit, and perhaps limit quite severely, additions to nature for the sake of the environment and of life on this planet seems eminently reasonable." ${ }^{\text {44 }}$ Most courts considering this question have reached the same conclusion. ${ }^{48}$

This interpretation of the reach of CERCLA liability is significant. Indeed, according to many in the business community, its practical impact cannot be overstated. ${ }^{46}$ The principal reason for this concern is that most cost recovery actions involve at least some parties whose individual contributions to a site arguably pose no significant health risks (low risk PRPs). ${ }^{47}$ CERCLA's provision for joint and several liability gives parties with clear and significant liability (major contributors) strong incentives to track down and implead as many other parties as possible; after all, as more parties are added to the suit, each of the original defendants' share of the damages shrinks accordingly. ${ }^{48}$ In seeking out every other potential defendant in this way, major contributors inevitably sweep in many low risk contributors as well, as evidenced by the fact that cost recovery actions often swell to include hundreds of PRPs. ${ }^{49}$ The rejection of a significant risk threshold, then, impacts

43 Id, citing S Rep No 848, 96th Cong, 2d Sess 24 (1980) (emphasis added).

457 F Supp at 538.

${ }^{45}$ Mid Valley Bank v North Valley Bank, 764 F Supp 1377, 1386-87 (E D Cal 1991); United States v Western Processing Co., Inc., 734 F Supp 930, 941-42 (W D Wash 1990); Brookfield N. Riverside Water Commission v Martin Oil Mktg., 1991 US Dist LEXIS 2045, *2-6 (N D Ill 1991); City of New York v Exxon Corp., 766 F Supp 177, 195-96 (S D NY 1991). But see Amoco Oil Co. v Borden, Inc., 889 F2d 664, 670-71 (5th Cir 1989); LouisianaPacific Corp. v Asarco, Inc., 735 F Supp 358, 362 (W D Wash 1990).

${ }_{43}$ Brief Amicus Curiae of the United States Chamber of Commerce, United States $v$ Alcan Aluminum Corp., No. 91-5481, 18-19 (3d Cir 1992)("Chamber of Commerce Brief").

47 Id at 18-20.

48 Id.

19 See Frederick R. Anderson, Negotiation and Informal Agency Action: The Case of Superfund, 1985 Duke L J 261, 266 n 10 (citing EPA estimates that it will identify over 50 PRPs at 10 to $25 \%$ of the sites); Lyons, 6 Stan Envir L J at 314 (cited in note 6) (noting the 
a surprisingly large percentage of the cases brought under CERCLA.

There is also a second reason to be concerned about Alcan's interpretation of the scope of CERCLA liability. Due to the incentives CERCLA creates for parties to settle, low risk PRPs may be forced to pay cleanup costs in excess of their pro rata share. PRPs that successfully negotiate a settlement with EPA, for instance, are immune from contribution suits by nonsettling PRPs. ${ }^{50}$ Failing to reach some sort of accommodation with EPA, then, exposes a PRP to liability for all remaining response costs, regardless of the PRP's actual contribution to the problem. As a result, settlements are the norm, not the exception, under CERCLA. ${ }^{51}$ This pressure to settle, however, places low risk PRPs in a compromised position. If larger than equitable payments are demanded by EPA (or by the major PRPs as a condition of joining their settlement with EPA), low risk PRPs have no choice but to accede to these terms; seeking a determination of their "proper" share of damages in court will most likely lead to an even less fair allocation because in that forum they will also be saddled with all unrecouped costs. ${ }^{82}$ The rejection of a significant risk threshold, then, threatens to impose disproportionately high costs (costs devastating to small and average size businesses) on a great number of relatively innocent parties. Thus, while the harms at stake in these controversies are trivial, the many interests at stake are not. ${ }^{\text {ss }}$

example of United States v Conservation Chemical Co., 619 F Supp 162 (W D Mo 1985), in which four major PRPs brought in 250 additional PRPs).

so 42 USC § 9613(f); O'Neill v Picillo, 682 F Supp 706, 729-30 (D RI 1988), aff'd, 883 F2d 176 (1st Cir 1989). But see Alcan II, 964 F2d at 270 n 29.

B1 A very small proportion of CERCLA cost recovery actions actually result in reported litigation. See Frederick R. Anderson, Daniel R. Mandelker, and A. Dan Tarlock, Environmental Protection: Law and Policy 643 (Little Brown, 1990). Indeed, EPA is on record for saying that it uses the threat of joint and several liability to encourage settlements. See Hazardous Waste Enforcement Policy, 50 Fed Reg 5034, 5037-38 (1985).

${ }^{82}$ An example is Alcan II, $964 \mathrm{~F} 2 \mathrm{~d}$ at $270 \mathrm{n} 29$, in which the lone holdout Alcan was held liable for one third of the response costs even though its wastes arguably posed no or only insignificant risk.

${ }^{38}$ Low-risk contributors can seek expedited settlements with EPA. 42 USC \& 9622(g). In practice, however, this provision provides little relief. EPA's authority to enter into such settlements is discretionary and is exercised quite begrudgingly. As of April of 1991, for instance, EPA completed only 35 such settlements with de minimis contributors. The Information Network for Superfund Settlements, DeMinimis Superfund Settlements DM-1-5 (Apr 1, 1992). 


\section{CERCLA's Statutory Language and a Significant Risk Threshold: AMOCO OIL Co. V Borden, INC.}

The court in Alcan imposed liability notwithstanding the insignificant risks posed by Alcan's release in part because it believed that CERCLA's language unequivocally ruled out the possibility of a significant risk threshold for liability. ${ }^{54}$ As this Section will show, however, this interpretation of the statutory language is incomplete. Although the requirement that the release contain a "hazardous substance" does not contemplate a significant risk threshold, other elements of the prima facie case set forth in $\S 107$ do support such a threshold.

The statutory basis for a significant risk threshold to CERCLA liability is outlined in Amoco Oil Co. $v$ Borden, Inc. ${ }^{\text {s5 }}$ The Amoco Oil Company brought a private CERCLA cost recovery action against Borden, Inc. to recover the costs of responding to hazardous wastes left on a tract of land Amoco had purchased from Borden in 1977. ${ }^{56}$ Prior to the sale, Borden manufactured a phosphate fertilizer at the site and stored the radioactive by-product phosphogypsum in a pile on the land..$^{57}$ Although phosphogypsum normally has a low level of radioactivity, Borden also dumped more highly radioactive wastes into both the phosphogypsum pile and at other locations on the property (called "off-pile" sites). ${ }^{\text {s8 }}$ Some of these "off-pile" sites emitted radiation exceeding the normal background radiation by 500 times. ${ }^{59}$ However, the radiation from the phosphogypsum pile, according to Borden's calculations, would result in no more than one additional cancer death every 400 years. $^{60}$ On this evidence, the district court found in favor of Borden and denied the recovery of response costs. ${ }^{61}$

On appeal, the Fifth Circuit Court of Appeals reversed the district court on the grounds that the wastes on Borden's property violated federal safety standards in several places (especially in the off-pile sites) and so were more significant than Borden had claimed. ${ }^{62}$ Nonetheless, the court agreed in principle with the lower court, holding that CERCLA does not impose liability on every re-

\footnotetext{
5475 F Supp at 540 .

ss 889 F2d 664 (5th Cir 1989).

ss Id at 666.

${ }^{87} \mathrm{Id}$.

ss Id.

so Id.

${ }^{60}$ Id at $670 \mathrm{n} 9$.

a1 Id at 667 .

62 Id at 671 .
} 
lease of hazardous substances, but instead on only those releases creating risks higher than some threshold level. ${ }^{83}$ The court reached this result by first analyzing CERCLA's definition of "response costs" and then using that definition to make sense of the requirement in $\S 107$ that a release must "cause the incurrence of response costs."

Under CERCLA, the court observed, "response costs" and "response actions" (courts treat these terms synonymously) ${ }^{64}$ are defined as either (1) "removal actions," such as "actions . . . necessary to prevent, minimize, or mitigate damage to the public health or welfare or to the environment, which may otherwise result from a release or threat of release"; or (2) "remedial actions," such as "actions ... to prevent or minimize the release of hazardous substances so that they do not migrate to cause substantial danger to present or future public health or welfare or the environment." Thus, "response costs" can only include those costs related to actions taken to prevent, mitigate, or minimize a danger.

With this definition in mind, the court turned to the requirement in $\S 107$ that the release must "cause the incurrence of response costs." ${ }^{\text {B6 }}$ It observed that in order to cause response costs, the release must actually threaten human health or the environment. ${ }^{67}$ According to the court, only such a release could cause actions designed to "prevent, mitigate or minimize" a danger; after all, a release posing no threat would not require minimization and so could not cause response actions as they are defined by CERCLA. ${ }^{68}$ For this reason, the court concluded: "To justifiably incur response costs, one necessarily must have acted to contain a release threatening the public health or the environment."

In order to determine when a release threatens human health, the court then turned to $\S 121$ and its specification of the circumstances under which a contaminated site will be deemed "clean."70 According to this section, human health and the environment are adequately protected if the contamination at the site complies with certain "legally applicable ... or relevant and appropriate" federal and state standards or requirements, commonly referred to as the

\footnotetext{
os Id at 670-71.

or See note 21 .

68 Amoco, 889 F2d at 669 n 7, quoting 42 USC § 9601(23)-(24).

66 42 USC § 9607(a)(4).

ar 889 F2d at 669-70.

68 Id.

6o Id at 670 (emphasis added).

${ }^{70}$ Id at 671.
} 
"ARAR requirements" or "ARARs." In other words, human safety is not considered at risk once a site contains no more of a particular pollutant than is permitted by the relevant ARARs; under $\S 121$, compliance with the ARARs "assures [the] protection of human health and the environment."72 It follows, then, that a release threatens public health only if it results in contamination exceeding the levels permitted by the applicable ARARs.

The court therefore concluded that a threshold for liability is built into the prima facie case under $\S 107$. A release "causes the incurrence of response costs" only if it is threatening. A release is threatening, in turn, only if it violates an ARAR. Thus, a release "causes the incurrence of response costs" only if it violates an ARAR. In other words, in order to prove liability, the plaintiff must show that the release results in contamination or risks of harm greater than those permissible under the applicable ARARs. ${ }^{73}$ As the court summarized:

[W]e believe that the question of whether a release has caused the incurrence of response costs should rest upon a factual inquiry into the circumstances of a case and the relevant factual inquiry should focus on whether the particular hazard justified any response actions. ${ }^{74}$

\section{CERCLA's Legislative History and a Significant Risk THReshold}

Courts rejecting a significant risk threshold for CERCLA liability insist that their interpretation of the reach of CERCLA's liability scheme finds support in CERCLA's legislative history. ${ }^{78}$ As this Section will show, however, this reliance on CERCLA's legisla-

${ }^{71} 42$ USC § 9621(d)(1), (d)(2)(A); Amoco, 889 F2d at 671. The ARARs list the acceptable, usually nonzero, levels of pollutants permissible in soil, water and air. See Donald A. Brown, EPA's Resolution of the Conflict Between Cleanup Costs and the Law in Setting Cleanup Standards Under Superfund, 15 Colum J Envir L 241, 264-68 (1990) (discussing nonzero ARARs for groundwater contaminants).

7242 USC \& 9621(d)(1).

7s The court in Amoco does state that the ARARs need not be the "exclusive means of justifying response costs." 889 F2d at 671 . It is not clear, however, what other standards the court had in mind. The ARARs in $\S 121$ represent CERCLA's only indication of how to measure when human health is adequately protected. As a result, they also necessarily constitute the only standard against which to measure whether a release is threatening, and so the only standard against which to measure whether a release justifies response costs and triggers liability.

34 Id at 670 .

7s See text accompanying note 44 . 
tive history is problematic, the materials being far more ambiguous than most courts have acknowledged. ${ }^{76}$ CERCLA's legislative history in fact contains several direct indications that Congress had no intention of extending liability to releases posing insignificant risks of harm.

At several points Congress focused directly on the problem of releases posing only de minimis risks to public health. Representative Stockman inveighed that an early draft of the CERCLA bill reeked of the "ideological goal of zero-discharge, zero risk" and that the "legislative concept that a site must pose 'likelihood of harm to public health and the environment' is utterly meaningless. Depending upon its interpretation, any release could 'harm the environment." "77

Echoing these concerns, Representative Martin expressed anxiety that liability might befall thousands of communities "where, inevitably some detectable traces of undesirable chemicals will be found."78 Seeking clarification and "in order that we might develop some legislative history," Martin queried of the bill's sponsor, Representative Florio: "Did the committee look at some standards of what would pose an unacceptable risk, thereby justifying cleaning up these sites and not other sites?"79 Florio was reassuring: "[W] hat we are trying to do is deal with those problems that currently are imminent hazards to the people's safety and to the envi-

7o It is important to keep in mind that, even in the best of circumstances, legislative history can provide only limited insight on matters of statutory interpretation. See Cass $R$. Sunstein, After the Rights Revolution at 127-30 (Harvard, 1990).

Moreover, Congress did not enact CERCLA under the best of circumstances. The bill that ultimately became law was hurriedly assembled from several earlier bills by a small group of congressmen, then presented on a take-it-or-leave-it basis to a lame duck Congress eager to pass some sort of hazardous waste bill. No committee report was prepared for the final bill, and only limited, highly-orchestrated debate was permitted. See generally Frank P. Grad, A Legislative History of the Comprehensive Environmental Response, Compensation and Liability ("Superfund") Act of 1980, 8 Colum J Envir L 1 (1982); Robert C. Eckhardt, The Unfinished Business of Hazardous Waste Control, 33 Baylor L Rev 253 (1981).

As a result, CERCLA has virtually no direct legislative history, and the legislative history commonly cited actually discusses provisions from earlier bills that were only partially incorporated into the final bill. Moreover, due to the frantic circumstances, statements on the floors of both houses directly pertaining to the final CERCLA bill are, as one court lamented, "unusually riddled by self-serving and contradictory statements." United States $v$ Wade, 577 F Supp 1326, 1331 (E D Pa 1983). Drawing conclusions from CERCLA's legislative history, then, must be done cautiously.

72 HR Rep No 96-1016 at 73-74 (cited in note 4) (dissenting views of Representatives Stockman and Loeffler).

7* 126 Cong Rec 26769 (Sep 23, 1980) (remarks of Representative Martin).

70 Id. 
ronment . . . ."80 As Florio advised Martin only moments earlier, "We are not turning EPA people loose to go dig up everything around the country."BI This colloquy strongly suggests that Congress did not intend CERCLA liability to attach to every release of hazardous substances.

Similar legislative history emerged from the Senate. In describing what would become $\S 103$ and its requirement that certain releases of hazardous substances be reported, ${ }^{82}$ one Senate report explained that each substance's reportable quantity is fixed without "any reference to harm or hazard." on to make an important clarification: "[R]eleases in such quantities trigger notification requirements, but do not, in and of themselves, give rise to other liabilities under this Act . . . " " This language suggests that Congress did not envision every release leading to liability; evidently, some releases would be significant enough to require notification, but not significant enough to create liability. Thus, although CERCLA's legislative history is far from unequivocal on this issue, it does contain evidence suggesting that both houses of Congress envisioned some form of significant risk threshold. ${ }^{85}$

so Id (remarks of Representative Florio) (emphasis added).

s2 Id.

8242 USC § 9603.

${ }^{83} S$ Rep No $96-848$ at 29 (cited in note 4).

84 Id (emphasis added).

ss That CERCLA does not demand zero risk has also been the long-standing position of EPA, notwithstanding its litigation posture in cases like Alcan. When deciding which federal standards the cleanup of contaminated groundwater must comply with, for instance, EPA considered two options: (1) the maximum contaminant level goals ("MCLGs"), promulgated under the Safe Drinking Water Act ("SDWA"), 42 USC $\$ 3300 \mathrm{f}-300$ j-26 (1991), which establish the maximum concentration in water of any pollutant such that no known or anticipated adverse human health effects will occur, with an adequate margin of safety, 42 USC \& $300 \mathrm{~g}-1(\mathrm{~b})(4)$; and the maximum contaminant levels ("MCLs"), again promulgated under the SDWA, which establish simply the maximum permissible concentration of any pollutant in water that may be delivered to any user of a public water system, 42 USC § 300f(3). Brown, 15 Colum J Envir L at 264-68 (cited in note 71).

Ultimately, EPA ruled that cleanup of some chemicals need only conform to the more lenient requirements of the MCLs (as opposed to MCLGs), even though at those levels a clear degree of risk remains. $40 \mathrm{CFR} \S 300.430(\mathrm{e})(2)(\mathrm{B})$. According to EPA, CERCLA itself dictated this result:

EPA also believes that MCLGs of zero are not appropriate for determining the actual cleanup levels to be attained under CERCLA because CERCLA does not require the complete elimination of risk or of all known or anticipated effects; i.e., remedies under CERCLA are not required to entirely eliminate potential exposure to carcinogens.

National Oil and Hazardous Substances Pollution Contingency Plan, 55 Fed Reg 8665, 8752 (1990). 


\section{CERClA's Purposes and a Significant Risk Threshold}

Perhaps the principal reason courts have resisted fashioning a significant risk threshold for CERCLA liability is the fear that limiting liability, even minimally, cannot be reconciled with CERCLA's public-minded goals. ${ }^{86}$ As this Section will show, however, this intuition is misplaced, at least with regard to CERCLA's three central ambitions: rapid cleanup, deterrence, and fairness. ${ }^{87} \mathrm{~A}$ significant risk threshold for liability is not only compatible with these goals, but actually furthers them.

\section{A. Rapid Cleanup}

A significant risk threshold is consistent with CERCLA's first goal of rapid cleanup. ${ }^{88}$ By restricting the ability of major contributors to implead numerous minor contributors and thereby complicate and prolong litigation, such a threshold would arguably accelerate the currently mired process of remedying the nation's hazardous waste sites.

One of the means by which CERCLA's drafters hoped to expedite the cleanup of contaminated sites was to make liable a broad range of parties. ${ }^{89}$ The Superfund created by Congress to finance the cleanup effort, originally set at $\$ 2.2$ billion for five years, ${ }^{90}$ could only remain viable if solvent, "responsible" parties could be located; without reimbursement from such parties, Congress feared, the limited resources of the fund would be quickly ex-

so See text accompanying notes 4-5.

s7 It should be noted that courts often characterize CERCLA as designed to ensure that responsible parties cover the costs of cleanup. See, for example, B.F. Goodrich Co. v Murtha, 958 F2d 1192, 1198 (2d Cir 1992). This "polluter pays" principle, however, is in fact less a goal than a means; CERCLA requires polluters to internalize the costs of the harms they produce not for any inherent reason but because doing so will deter further pollution, restore equity to innocent victims, and so forth. Any inquiry into CERCLA's purposes, then, should focus on these more fundamental concerns.

${ }^{8 s}$ See, for example, 126 Cong Rec 30983 (Nov 24, 1980) (remarks of Senator Jepsen) ("Where health threats are imminent, quick corrective action is necessary."). See also 126 Cong Rec 30945 (Nov 24, 1980) (remarks of Senator Danforth) ("Clearly we have no time to lose. . . . Although there are many differences among Members of the Senate, I believe the clear consensus is that we must clean up abandoned hazardous dump sites as soon as possible.").

89 Note, 99 Harv L Rev at 1517 (cited in note 11); Comment, Generator Liability under Superfund for Clean-up of Abandoned Hazardous Waste Dumpsites, $130 \mathrm{U}$ Pa L Rev 1229, 1232 (1982).

${ }^{90} 42$ USC \& $9632(b)(2)$ (1982). In 1986, when the original five year-period came to an end, Congress authorized the fund to include $\$ 8.5$ billion for five additional years. 42 USC § 9611(a) (1988). 
pended and cleanup efforts would grind to a halt. ${ }^{91}$ The imposition of joint, several and retroactive liability, together with the expansive definition of "covered persons," was intended, in part, to fill this need. Under such a regime, EPA would ideally find someone to hold responsible for each site, no matter how long abandoned or inactive, and remediation could thus proceed at a rapid rate.

In practice, however, cleanup under CERCLA has been anything but rapid. Of the more than 30,000 potential cleanup sites, only forty-one had been cleaned as of $1989 . .^{83}$ Partly responsible for this disappointing performance is, ironically, the very liability scheme CERCLA's drafters thought would accelerate cleanup. ${ }^{94} \mathrm{By}$ enabling EPA to virtually always find some potentially responsible party, CERLCA's liability scheme also enables the party tagged by EPA to find another party from whom it can seek contribution. Once brought into the lawsuit, this third party impleads still additional parties to minimize its own share of damages. As a result, CERCLA litigation often involves hundreds of parties, each maneuvering for the most advantageous allocation of costs, and settlement negotiations drag on for years. ${ }^{95}$ CERCLA's liability scheme, then, works at cross purposes: at the same time it enhances cleanup efforts by ultimately ensuring for the recovery of costs, it also creates a beastly snarl of litigation that siphons off scarce resources, impedes the immediate recovery of costs, and delays cleanup. ${ }^{98}$

91 See, for example, Comment, $130 \mathrm{U} \mathrm{Pa}$ L Rev at 1232 (cited in note 89).

${ }^{92}$ See text accompanying notes 13-15.

3 Richard Delgado, Our Better Natures: A Revisionist View of Joseph Sax's Public Trust Theory of Environmental Protection, and Some Dark Thoughts on the Possibility of Law Reform, 44 Vand L Rev 1209, 1217 n 54 (1991).

84 Lyons, 6 Stan Envir L J at 271-72 (cited in note 6) ("Unfortunately, the process of encouraging or forcing responsible parties, either initially or subsequently, to finance the cleanup of hazardous waste sites tends to significantly impede overall progress towards CERCLA's primary goal of eliminating the immediate and long-term threats to human health and the environment posed by the nation's worst hazardous waste sites."); Jan Paul Acton, Understanding Superfund: A Progress Report, 53-54 (Rand 1989) (CERCLA's joint and several liability scheme may play a role in the costly delay prior to cleanup).

${ }^{95}$ Lyons, 6 Stan Envir L J at 316-18 (cited in note 6).

o6 It has been estimated that the transaction costs involved in the government's efforts to have PRPs fund and undertake site response actions at 1,800 sites on the National Priorities list could equal or exceed $\$ 8$ billion, or roughly the cost of cleaning up 400 to 450 heavily contaminated sites. Insurance Issues and Superfund: Hearing Before the Senate Committee on Environment and Public Works, 99th Cong, 1st Sess 134-37 (1985) (statement of John C. Butler III, Director, Putnam, Hayes, and Bartlett, Inc.). Indeed, a recent study by the Rand Institute found that $88 \%$ of funds spent on old toxic waste sites went to cover legal fees and other transactional costs, rather than actual cleanup. Environmentalism Runs Riot, The Economist 11 (Aug 8, 1992). 
A significant risk threshold would partially resolve this tension. Such a threshold would reduce the number of parties that could be impleaded and, consequently, facilitate settlements with major contributors. Indeed, this very insight led Congress, when it reauthorized CERCLA in 1986, to give EPA authority to seek expedited settlements with parties contributing de minimis quantities of waste. ${ }^{97}$ Of course, such a threshold could possibly lead to some increase in court litigation by encouraging parties on the margin to seek to have their releases declared de minimis. Overall, however, the speed of allocating cleanup responsibilities should increase. A significant risk threshold would suddenly make any efforts by a major contributor to shift its costs quite expensive and risky (rather than free, as the situation stands now), and, as a result, the incentives to resolve cleanup matters as early as possible through out-of-court negotiations would grow accordingly.

\section{B. Deterrence}

A significant risk threshold would also enhance CERCLA's goal of deterrence. ${ }^{98} \mathrm{By}$ correcting for the skewed incentives created by CERCLA's liability scheme, such a threshold may induce companies to use better disposal practices.

Although CERCLA's drafters envisioned that CERCLA would deter improper waste disposal, the statute may not have this effect. The reason for this anomaly lies with the incentives-or, rather, the lack of incentives-created by CERCLA's combination of joint and several liability with an easily triggered liability scheme. As Professor Epstein has observed, joint and several liability virtually eliminates the incentive to take precautions that merely reduce liability. ${ }^{99} \mathrm{He}$ posits a scenario in which ten companies each contribute $\$ 2,000$ of damages to a site. Under a regime of joint and several liability, each would have a one in ten chance of being held liable for the entire loss, or $\$ 20,000$, and so each would face, appropriately, an anticipated liability of $\$ 2,000$. Suppose further that one company discovers that it can spend $\$ 500$ and cut its share of the damages in half, to $\$ 1,000$. Although less advantageous than elimi-

$" 42$ USC § 9622(g).

" Disasters like the one at Love Canal in New York highlighted the need for some mechanism to deter improper disposal of hazardous wastes in the first place. According to CERCLA's drafters, CERCLA's liability scheme would accomplish just that because it would create a compelling incentive to prevent releases and thus protect the public from harm. S Rep No 96-848 at 31 (cited in note 4).

" Richard A. Epstein, Two Fallacies in the Law of Joint Torts, 73 Georgetown L J 1377, 1385-86 (1985). 
nating the company's share of damages entirely, this precautionary investment is nonetheless worthwhile; total damage at the site would fall from $\$ 20,000$ to $\$ 19,000$, at a cost of only $\$ 500$.

A rule of joint and several liability, however, removes the incentive to take this precautionary investment. Because the company would still face a one in ten chance of being held liable for the total damage at the site (now $\$ 19,000$ ), its personal anticipated liability after the investment would drop to only $\$ 1,900$; the $\$ 500$ investment, in other words, would save a mere $\$ 100$. The real winners would be the other nine parties who, through no action of their own, would also see their anticipated liability drop to $\$ 1,900$. Under joint and several liability, parties collectively share not only the costs of any damage, but also the benefits of any precautions. Joint and several liability, therefore, sharply limits the circumstances in which a party would find efforts to reduce liability to be in its best interest. ${ }^{100}$

CERCLA's cruel irony is that at the same time it removes the incentive to reduce liability, it also virtually eliminates the possibility of avoiding liability. A manufacturer that uses or produces hazardous wastes in the course of its business has only a limited range of options short of entirely shutting down. First, it could find a nonhazardous substitute to use in its manufacturing process, a route that most companies probably find unrealistic due to the constraints of cost and technology and the fact that so many substances are listed as hazardous under CERCLA. ${ }^{101}$ Second, it could possibly treat its waste in such a way as to render it nonhazardous, although the technology for such permanent solutions is extremely limited ${ }^{102}$ and often prohibitively expensive. ${ }^{103}$ Finally, the manufacturer can consign its wastes to off-site disposal in a licensed hazardous waste landfill.

Most companies will choose this option, although it has some potentially dire consequences under CERCLA. First, disposal in this manner entails burying the wastes, and even if facilities use

100 Id.

101 Edward Yang and James Tracy, Superfund Technology-A Long-Run Perspective, 4 Envir Forum 40, 41 (Jan 1986).

${ }^{102}$ Lucero Says EPA Faces Serious Questions on Superfund Revisions, 17 Envir Rep 962 (BNA)(Oct 24, 1986) (remarks of Gene A. Lucero, Director of EPA's Office of Waste Programs Enforcement).

${ }^{103}$ High Cost of Permanent Superfund Cleanups, 17 Envir Rep 778 (BNA) (Sep 26, 1986) (remarks of J. Winston Porter, Assistant EPA Administrator for Solid Waste and Emergency Response) ("There's probably not enough money in the world to clean up all the sites permanently."). 
the most advanced leacheate collections systems, buried wastes always have the ability to leak, migrate, and create health or environmental risks. ${ }^{104}$ If they do, the company may find itself liable for the costs of rectifying the situation, even though it took every prudent measure, because CERCLA's standard of liability treats these measures as irrelevant. ${ }^{105}$ Second, even if the company's own wastes remain confined in the landfill, the company may nonetheless find itself responsible for remedial measures if other, chemically similar wastes are released. ${ }^{108}$ In sum, CERCLA's tight liability scheme means that no one associated with toxic wastes can act in such a way as to be confident of avoiding its snare.

The effect of this combination of joint and several liability with a very sensitive liability trigger is quite startling. By eliminating the incentive to reduce liability at the same time it makes avoiding liability next to impossible, CERCLA not only fails to deter poor disposal practices, but it may in fact encourage them. As Professor Epstein observed:

Why worry about taking precautions if the benefit will go to other users of the waste site? Instead, the optimal strategy, which some firms will follow, is to save by reducing precaution costs. Here the savings that any one firm achieves could be substantial, and the loss that it creates will be borne not by it, but by other firms. The total level of pollution therefore could be expected to increase beyond what it would be if each firm were held responsible for its pro rata share of the loss. ${ }^{107}$

No doubt the simple cost/benefit analyses posited in Professor Epstein's scenario trivialize to some degree the enormous scientific and other uncertainties that characterize real-life toxic waste management; quite often would-be polluters cannot accurately gauge their potential exposure to liability, and many do choose to make precautionary investments. This concern, however, only goes so far. As scientific knowledge in this area becomes more sophisticated, parties will increasingly be able to estimate their risks and so will find themselves increasingly paralyzed by the collective action problem at the heart of CERCLA's liability scheme.

\footnotetext{
104 Yang and Tracy, 4 Envir Forum at 43 (cited in note 101) (current containment and disposal technologies have terms of effectiveness of only 8 and 30 years, respectively).

105 See text accompanying notes 7-8.

${ }^{108}$ See, for example, Amoco, 889 F2d at 670 n 8; United States v Monsanto Co., 858 F2d 160, 169 (4th Cir 1988).

${ }^{107}$ Epstein, 73 Georgetown L J at 1386 (cited in note 99) (emphasis in original).
} 
A significant risk threshold would help to correct these perverse incentives and undo the collective action problem. ${ }^{108}$ Whereas currently a company has few options (short of shutting down) for avoiding CERCLA liability, under a regime with a significant risk threshold it could potentially have at least one more. For instance, although a company may not be able to replace all its toxic substances, it may be able to substitute for some of them such that its use of toxins, while not zero, at least stays within health limits. ${ }^{109}$ Most importantly, since the company would avoid liability entirely by taking such action, it would not share its benefits with other contributors and so would be more likely to take them in the first place. Thus, by raising to a more realistic, achievable level the point at which parties escape liability, a significant risk threshold would restore the incentives for better hazardous waste management that CERCLA's drafters envisioned but which their unwitting combination of wide and tight liability put out of reach:

\section{Fairness}

Finally, a significant risk threshold is also compatible with CERCLA's concern for fairness. ${ }^{110}$ Although it may at first seem counterintuitive, the notion of fairness embraced by CERCLA would not deem endurance of a low-level risk "unfair."

CERCLA's drafters firmly believed that compensation should be tendered to those injured by hazardous wastes unfairly; individuals should not have to pay the cost of cleaning up contamination they had no part in creating:

Though [CERCLA's liability scheme] may impose harsh results on certain defendants, it is the most equitable solution in view of the alternative - forcing those who bear no responsibility for causing the damage ... to shoulder the full cost of clean up. ${ }^{111}$

${ }^{108}$ So too might eliminating joint and several liability, but that would greatly reduce EPA's ability to recover its costs and would thereby threaten the viability of the Superfund.

${ }^{109}$ See Chamber of Commerce Brief at $20 \mathrm{n} 14$ (cited in note 46).

110 One Senate Report crisply articulated this concern:

One additional purpose of [CERCLA's] strict liability scheme is to assure that the costs of injuries resulting from defective or hazardous substances are borne by the persons who create such risks rather than by the injured parties who are powerless to protect themselves. . . . The issue is really one of fundamental fairness.

$S$ Rep No 96-848 at 33 (cited in note 4)(emphasis added).

111 United States v Price, 577 F Supp 1108, 1114 (D NJ 1983). 
CERCLA's supporters repeatedly emphasized that one of the bill's primary concerns was to ensure equity for the innocent victim and some form of relief for those wronged by the discharge of hazardous wastes: "[W]e sought to protect unsuspecting victims from unanticipated releases of hazardous substances ...."112

However, determining when a party is "innocent" or has suffered risks of harm "unfairly" is complex. As Professor Fletcher explains, a victim's right to recover has traditionally turned on whether the risk-producing activity was reciprocal: "[W]e are subject to harm, without compensation, from background risks, but [] no one may suffer harm from additional risks without recourse for damages against the risk-creator." 113 .A party suffers risks of harm "unfairly," in other words, when she must endure risks different in kind or greater in degree than those she has imposed on everyone else; subject to more than her fair share of risk, the party deserves compensation.

Exact reciprocity has never been necessary, however, especially when the risks at issue are relatively low. Courts have traditionally seen no unfairness in denying compensation for those suffering only insignificant risks of harm, as Baron Bramwell explained in Bamford $v$ Turnley: ${ }^{114}$

It is as much for the advantage of one owner as of another; for the very nuisance the one complains of, as the result of the ordinary use of his neighbour's land, he himself will create in the ordinary use of his own, and the reciprocal nuisances are of a comparatively trifling character. The convenience of such a rule may be indicated by calling it a rule of give and take, live and let live. ${ }^{115}$

Parties suffering relatively minor, albeit nonreciprocal, risks do not suffer them unfairly because they do receive compensation of a

112 S Rep No 96-848 at 121 (cited in note 4) (additional views of Senators Domenici, Bentsen, and Baker). This principle of equity for the innocent victim represents a conception of fairness different from, but every bit as viable as, that of corrective justice-namely, that every injured person deserves a remedy against his wrongdoer. As Professor Fletcher explains: "Whether the victim is entitled to recover and whether the defendant ought to pay [ ] are distinct issues." George P. Fletcher, Fairness and Utility in Tort Theory, 85 Harv L Rev 537, 540 (1972).

113 Fletcher, 85 Harv L Rev at 550.

214122 Eng Rep 27 (1862).

125 Id at 33. See also Elizabeth Ann Glass, Superfund and SARA: Are There Any Defenses Left?, 12 Harv Envir L Rev 385, 409-10 n 185 (1988) ("the fact that there was only a de minimis release would weigh heavily in favor of finding the purchaser not liable for the nuisance"). 
sort. Rather than money for their injuries, they receive the assurance that the equivalently small hardships they impose on everyone else at some later time will be similarly nonactionable. As Professor Epstein explains, what such parties do not receive today roughly equals what they would otherwise have to pay out tomorrow:

[T] here is a high degree of implicit in-kind compensation between parties. The nuisances here are of such common and frequent occurrence that it is safe to assume that virtually all persons will be in separate individual instances both wrongdoers and victims. The high frequency and low intensity of claims suggests that they will ... most likely balance out. ${ }^{118}$

This rule may seem harsh if one focuses on individual cases in isolation, but over the mine run of cases it certainly assures equity (and minimum cost) for everyone.

Given this understanding of fairness, excusing from liability releases posing only low-level risks of harm would not be "unfair." The increased health risks suffered by some would ultimately be canceled out by the increased risks, albeit in another form, that they will surely impose on others at some future date; rather than receiving cash now, they will instead simply not have to pay out later. To be sure, some asymmetry exists between the risks generated by everyday life and the risks associated with toxic wastes, but this point only goes so far. As Representative Stockman observed, households discharge "hazardous" chemicals into the environment virtually everyday. ${ }^{117}$ These "releases" can occur in sundry, seemingly innocuous forms, such as the disposal of mothballs (naphthalene) and even rubbing alcohol (methanol). ${ }^{118}$ Indeed, EPA has acknowledged that one percent of the waste generated in the average household constitutes hazardous materials falling within CERCLA's ambit. ${ }^{119}$ That consumers are implicated in toxic risk creation weakens the asymmetry claim and justifies, on fair-

${ }^{116}$ Richard A. Epstein, Nuisance Law: Corrective Justice and Its Utilitarian Constraints, $8 \mathrm{~J}$ Legal Stud 49, 84 (1979).

117126 Cong Rec 26759 (Sep 23, 1980) (remarks of Representative Stockman).

118 Id.

11 Fact Sheet, EPA Initiative to Address Municipal Issues, in Chamber of Commerce Brief, at 19 (cited in note 46). EPA has chosen to exempt homeowners from liability for these household wastes. See Alcan II, 964 F2d at $264 \mathrm{n} \mathrm{21.} \mathrm{Certainly} \mathrm{it} \mathrm{is} \mathrm{anomalous} \mathrm{to}$ impose liability in one instance and not the other when the risks at stake are arguably equivalent. 
ness grounds, exempting from liability releases posing de minimis risks.

\section{Practicality and a Significant Risk Threshold}

Even though CERCLA's language, legislative history and declared purposes suggest that the statute contemplates a significant risk threshold for liability, two further concerns remain. First, some have argued that because uncertainties endemic to quantitative risk analysis render accurate predictions of risk unlikely, a regime relying on such predictions would be unsound and unworkable. Second, some courts have claimed that because many sites have become contaminated through the small contributions of numerous parties, a regime that did not impose liability on such parties would leave these sites without anyone to foot the bill. As this Section will show, however, these concerns about the implementation of this rule are largely overblown. Notwithstanding its limitations, quantitative risk assessment has been, and necessarily will continue to be, a mainstay of CERCLA enforcement, and the fear of exempting all relevant PRPs is unfounded.

\section{A. Quantitative Risk Assessment}

Few dispute that efforts to determine the magnitude of the health risks posed by hazardous substances at a site are fraught with imprecision and uncertainty. The reasons for such skepticism are numerous:

(1) [E]pidemiological data relating to dose rates to human disease does not exist for most problems; (2) extrapolating doseresponse results from animals to humans requires the selection of untested assumptions; (3) effects of exposure may take years or generations to materialize for chronic diseases; (4) human experimentation is excluded on ethical grounds; (5) experiments must assume some dose rates, thereby giving no information about other dose rates; and (6) exposure assessments must rely upon complex models that attempt to describe how pollutants may be transported through air, water, and soil and thereby create exposure opportunities to humans and animals. ${ }^{120}$

${ }^{120}$ Donald A. Brown, Superfund Cleanups, Ethics, and Environmental Risk Assessment, 16 BC Envir Aff $\mathrm{L}$ Rev 181, 187-88 (1988). This catalogue of ills, moreover, is far from comprehensive. For a discussion of these and other difficulties inherent in risk analysis, see L. Daniel Maxim, Problems Associated with the Use of Conservative Assumptions in Expo- 
Lacking full knowledge for these and many other steps in the risk assessment process, the risk assessor must necessarily rely on assumptions for which there is no $a$ priori scientific basis; risk assessment procedures consequently often rely upon value judgments rather than science. As one group of EPA commentators has observed, at the same time that one model predicted the lifetime health risks from consuming drinking water containing fifty microgxams per liter of trichloroethylene to be approximately one percent, another model predicted the risks to be less than $0.000000001 \%$ : "These estimates provide a range of uncertainty equivalent to not knowing whether one has enough money to buy a cup of coffee or pay off the national debt."121 The many assumptions embedded in risk assessment thus cast doubt on the apparent precision implied by quantification.

Acknowledging the limitations of quantitative risk assessment, however, does not necessarily undermine the viability of a significant risk threshold for CERCLA liability. Such a threshold test remains sensible because risk assessments, reliable or not, are an integral part of CERCLA's operation. The extent to which a contaminated site should be rectified, for instance, turns fundamentally on just such evaluations of risk. All remedial action under CERCLA is governed by $\S 121$, which states that a cleanup must "assure[] protection of human health and the environment."122 $A$ cleanup will achieve this goal, in turn, only if it ensures that the site attains "legally applicable or relevant and appropriate" ARARs. ${ }^{123}$ Thus, in the case of contaminated groundwater, no more of a particular pollutant may remain than that amount permitted by the maximum containment levels (MCLs) promulgated under the authority of the Safe Drinking Water Act (SDWA). ${ }^{124}$ MCLs, however, like most ARARs, are calculated by performing a quantitative risk assessment from which an acceptable, "safe" level of contaminants is derived. Moreover, in situations where no ARARs apply, EPA has embraced risk analysis explicitly, stating that a cleanup in those circumstances will be judged "acceptable"

sure and Risk Analysis, in Dennis J. Paustenbach, ed, The Risk Assessment of Environmental Hazards 526, 534-39 (Wiley \& Sons, 1989); Symposium: Risk Assessment in Environmental Law, 14 Colum J Envir I 289-624 (1989); Brown, 15 Colum J Envir L at 285 n 182 (cited in note 71).

${ }_{122}$ C. Richard Cothern, William A. Coniglio, and William L. Marcus, Estimating Risk to Human Health, 20 Envir Sci \& Tech 111, 115 (1986).

12242 USC § $9621(d)(1)$.

${ }^{123} 42$ USC $\S 9621(d)(2)(A)$.

124 See note 85 . 
so long as the remaining health risks from carcinogenic substances lie between 1 in 10,000 and 1 in 1,000,000. ${ }^{125}$ Cleanups under CERCLA, then, depend fundamentally on quantitative risk assessments. Thus, the response to those who worry that a significant risk threshold would introduce an unworkable component into CERCLA is quite simple: it is already there.

\section{B. Multi-Polluter Contexts}

Some courts have also questioned the practicality of a significant risk threshold for liability on the grounds that it would improperly leave many sites unremediated or unfairly burden plaintiffs with excessive costs. The decision in United States $v$ Alcan Aluminum Corp. ("Alcan II"), ${ }^{128}$ for instance, emphasized this concern. In Alcan II, the Third Circuit considered an appeal from a case involving a situation very similar to that in the Alcan case discussed earlier. Addressing Alcan's claim that a small release of wastes could not have "caused the incurrence of response costs," the court acknowledged the persuasive reasoning in Amoco, but nonetheless insisted that the Fifth Circuit decision was distinguishable. ${ }^{127}$ The environmental injury at issue in Amoco resulted from one generator's pollution, whereas Alcan was but one of many contributors responsible for the current contamination. ${ }^{128}$ As the government noted, this distinction was significant:

[I]t is entirely possible for a hazardous waste facility to be comprised of entirely small amounts from many contributors. If each PRP could make [Alcan's] argument, i.e., that its particular contribution did not warrant remediation and thus that it should not be liable for any costs, no party would be liable, despite the fact that the site, as a whole, needed to be cleaned up and the government incurred costs in doing so. ${ }^{129}$

Individual defendants must be held responsible for environmental injury brought about by the actions of multiple defendants, the court concluded, even if no single defendant itself could have produced the harm. ${ }^{130}$ Otherwise, each defendant in a multi-defendant case could avoid liability by relying on the low concentrations of

\footnotetext{
12340 CFR $\S 300.430(\mathrm{e})(2)(\mathrm{i})(\mathrm{A})(2)$.

228 964 F2d 252 (3d Cir 1992).

127964 F2d at 266.

${ }^{228}$ Id.

120 Id at 267-68, quoting United States v Western Processing Co., 734 F Supp 930, 937

(W D Wash 1990).

1s0 Id at 267-71.
} 
hazardous substances in its waste, thus sticking plaintiffs with the substantial cleanup costs associated with accumulated wastes. ${ }^{131}$

Given the actual profile of CERCLA litigation, however, this argument is questionable. Only if the typical CERCLA action involves exclusively low risk contributors would the Third Circuit's anxiety be well-founded; only in that event would a significant risk threshold leave the government and private plaintiffs without parties to provide reimbursement. The true demographics of CERCLA actions, however, are not that bizarre. Most CERCLA actions predictably include major contributors and medium-sized contributors along with low risk contributors; most sites have received large amounts of waste from a few parties and progressively smaller amounts from other parties. ${ }^{132}$ Thus, even if a disproportionate number of parties to a CERCLA action were low risk contributors, exempting such parties from liability would nonetheless leave at least some major contributors to assume the cleanup burden. ${ }^{133}$ It seems unlikely, then, that the government would ever be left holding the bag.

\section{CONCLUSION}

Most courts have vigorously resisted the argument that CERCLA contemplates a significant risk threshold for liability. As this Comment has shown, however, this position is questionable. First, a significant risk threshold is consistent with CERCLA's statutory language, as the Amoco decision demonstrates. Second, the concept of a threshold for liability finds support in the legislative history. Finally, a significant risk threshold would arguably advance the statute's declared objectives because it would expedite settlement negotiations and provide incentives for proper disposal. Commentators and parties to CERCLA litigation have repeatedly insisted that public policy and common sense demand a threshold

131 Id.

132 See Anderson, 1985 Duke L J at 266 (cited in note 49) (citing EPA estimates that up to $75 \%$ of sites involve less than 50 contributors).

133 This is not to say, however, that a significant risk threshold in multi-polluter contexts would present no complications whatsoever. Consider, for instance, the problem of symergistic or potentiating effects. If numerous toxic substances are commingled at a site, a party's otherwise low risk release might chemically interact with another party's release such that together the substances pose risks of harm greater than simply the sum of the risks they would pose individually. Most likely, in such a situation, the low risk contributor should not be exempted from liability. Multi-polluter contexts raise such problems, but they hardly render a significant risk threshold impossible to administer. 
test for liability. What this Comment has tried to show is that CERCLA itself demands this test as well.

There is an additional, more universal problem with the decisions rejecting a significant risk threshold for CERCLA liability. Informing these decisions, as well as decisions in many other areas of CERCLA jurisprudence, is the interpretive principle that courts should "construe [CERCLA's] provisions liberally to avoid frustration of [its] beneficial legislative purposes."134 More liability, in other words, should mean more of a good thing. No doubt this canon of construction was conceived with the noblest of intentions, and no doubt it simplifies the unglamorous and difficult task of unravelling CERCLA's byzantine features and real-world ramifications. What is doubtful, however, is whether this and similar interpretive principles actually serve the statute well. More liability for de minimis risks, for instance, does not translate into more speed, more deterrence, or more fairness. Overall, it is probable that the same combination of forces within CERCLA that caused this counterintuitive result can cause other well-intentioned but unreasoned approaches to the statute to have similarly untoward systemic consequences. Simplifying maxims like "more is better," in other words, are double-edged: the statutory complexity that makes them seductive will likely make them invidious as well.

134 Dedham Water Co. v Cumberland Farms Dairy, Inc., 805 F2d 1074, 1081 (1st Cir 1986). See also United States v Mottolo, 605 F Supp 898, 902 (D NH 1985); United States v Conservation Chemical Co., 619 F Supp 162, 192 (W D Mo 1985). 
